\title{
INVESTIGATING INFORMATION USEFULNESS OF YOUTUBE AMONG SELECT UNIZIK STUDENTS
}

\author{
Gloria Nneka Ono \\ Mass Communication Department \\ Nnamdi Azikiwe University, Awka \\ Anambra State, Nigeria \\ nne_ka07@yahoo.com
}

\section{Chiazor Anthonia Chiaghana}

Mass Communication Department

Nnamdi Azikiwe University, Awka, Anambra State, Nigeria

chiazochiazo3@gmail.com

\section{Adaobi Olivia Okeke}

Mass Communication Department

Nnamdi Azikiwe University, Awka,

Anambra State, Nigeria

findolivia2k3@gmail.com

\begin{abstract}
The prevalence of YouTube has overwhelmingly expanded globally following its advent in 2005. Globally, opinions differ as to whether YouTube is a very useful information and knowledge source. The potentialities of YouTube offer a participatory, informational and knowledge-filled platform. Despite these potentials, research shows that YouTube in Nigeria does not yet enjoy much patronage. The study was aimed at determining the perceptions of Unizik students towards information usefulness of YouTube. It sought to find out among others the extent of YouTube use among the students and was anchored on Technology Acceptance Model (TAM) which posits that users will be willing to make use of a new technology if they find it useful and easy to use. The research design was survey and questionnaire served as the measuring instrument. Data were analysed using frequency tables and pie charts. The study found out that 75 percent of students use YouTube to a large extent amidst its challenges and that and that they had positive perceptions towards YouTube as a useful and significant source of information and knowledge. The researchers recommend that government should subsidize the cost of data for accessing the site since the respondents saw it as a major challenge. Also, more research is recommended to find more ways of combating other disclosed challenges such as unavailability of internet connectivity, poor patronage as content creators etc in YouTube use so as to avail students the opportunities of harnessing the potentials YouTube offers.
\end{abstract}

Keywords: Perception, YouTube, Media Use, Video sharing Site, New Media Technology

\section{INTRODUCTION}

In an age of information proliferation, the scare has been on what is really true and credible; reliable and unreliable especially on the internet as a tool that has eased access to information. Among the excellent developments that came with the internet age, the Web 2.0 is the website https://youtube.com commonly called YouTube (Wesch, 2008). Founded in 2005 by three PayPal employees: Chad Hurley, Steve Chen, and Jawed Karim, YouTube has become one of the most sought-after websites for information globally confirming what Iqbal (2020) stated that YouTube has gone on to become one of the world's most ubiquitous apps. It is the most popular video platform and is ranked as the second-most popular social network after Facebook (Statista, 2021) cited in (Mohsin, 2021). It generates more traffic in the internet world (Daniel, 2021). Moshin goes on to say that YouTube's latest statistics shows that YouTube has 2.3 billion users globally as at 2021 . 
DOI: doi.org/10.47851/naujocommed.v2i1.113

Its popularity has continued to be on the increase which is made possible due to its ease of access, friendliness and its localization in over 100 countries (YouTube, 2021) cited in (Mohsin, 2021). It adapts to different languages; 80 languages out of which 28 percent are in English language. YouTube was particularly created to cater for the participatory culture thus making its audience both consumers and producers of content which is perhaps another reason for its popularity in the world today.

YouTube in Nigeria is obviously used by entertainers, news corporations, young adults and teenagers alike. YouTube was launched in Nigeria in 2011 by Google (Online Media, 2011; Daniel, 2021). Through the local interface, www.youtube.com.ng, informative and entertaining video contents both locally and globally are offered by YouTube Nigeria. At the launch in Lagos, YouTube's senior director of Content Partnerships: Europe, Middle East and Africa, Patrick Walker, was quoted to have said that launching YouTube locally help people to find the most popular videos in Nigeria including those that are rising in popularity (Online Media, 2011).

Commenting on the adoption of YouTube in Nigeria, Ho (2017) posits that Nigeria is among the countries with accelerating YouTube localization with YouTube Go. Nigeria is the second country after India to have the YouTube Go capacity (Busari \& Osman, 2017). YouTube Go, is a platform where users with slow internet can preview, download and save videos. It costs much to buy data for this preview/download and at times internet connectivity is slow but with YouTube Go, users can always re-access the videos offline or without an internet connection after the initial download. Re-accessing YouTube videos without internet connectivity is a plus as far as saving data cost is concerned but more needs to be done to have free access of the videos at the preview and download level. This would help more Nigerians to be more visible on YouTube. YouTube Feather was introduced to help solve slow internet challenge but the truth is that slow internet connectivity is still a challenge in Nigeria. Many other launches have also been made showing that Nigeria is ripe with YouTube. Kazeem (2017) asserts: 'Google is also deepening its product offering in Nigeria including improving its Maps service which has seen Nigerian users numbers double in the past one year'.

Sadly, YouTube in Nigeria does not yet enjoy much patronage. Clement (2019) states that it is worrisome to know that even though many Nigerians use the internet, their poor use of YouTube means lower earnings for YouTubers in Nigeria who monetize their videos. Rating YouTube and other social media usage in Nigeria in 2020, the number of social media users in Nigeria was roughly 28 million out of which 81.6; approximately 82 percent, was YouTube users (Varrella, 2021). Social media stats in Nigeria in March 2021 (StatCounter, 1999-2021) shows percentages of the Facebook users as 53.29\%; Twitter, 24.35\%; Instagram, 10.97\%; Pinterest, 8.17\%; YouTube, 2.38\%, and LinkedIn, 0.65\%. The 2.38 percent of YouTube users in Nigeria implies that Nigeria is rated as low YouTube users.

Again, Digital report 2021 shows that out of 208.8 million Nigerians, only 33 million are active on social media, which is just about 15.8 percent of the nation's population (John, 2021). Judging from both figures (28 million in 2020 and 33 million in 2021), it can be adduced that Nigerians are not active on social media of which YouTube is one. Analysis of the 33 million according to the Digital report shows that WhatsApp is rated as the most active social media platform in Nigeria with over 93 percent users, Facebook is second at 86.2 percent, and YouTube is third at 81.6 percent. 
YouTube's content is not restricted to entertainment (Lee et al, 2020, p.1). It can be a good educational information source as YouTube can provide unlimited opportunities to enhance your eLearning course (Pappas, 2015). Pappas maintains that eLearning videos can be a very powerful tool as they add a dynamic element to eLearning courses, improve knowledge transfer, demonstrate complex procedures, and help explain difficult topics. These good sides of eLearning videos describe YouTube as a useful source of information in education. YouTube is also a lucrative site (Chau, 2010) cited in (Ahlquist, 2016): 'These individuals (Teens) use their videos as a main source of income'.

\section{STATEMENT OF RESEARCH PROBLEM}

The rating of YouTube use in Nigeria greatly differs from what is obtained on the world stage. There is low YouTube usage in the country and also an unending debate about YouTube's usefulness as a source of information and knowledge. Scholars like Catapano (2009-2019), Ahlquist (2016), Zhu (2017) etc upholds the information usefulness of YouTube while other scholars like Gonzalez (2016), Pant et al. (2012) perceive YouTube as an unreliable source based on the argument that anyone can create and upload information on the site.

The questions to ponder are therefore: Do Nnamdi Azikiwe University (UNIZIK) students make good use of YouTube? Do they have positive or negative perception towards the information usefulness of YouTube and do they have challenges in using the technology that brought about this poor usage? Does their perception have any relationship with the poor viewership of the site?

\section{OBJECTIVES OF THE STUDY}

The aim of the study was to investigate the perception of UNIZIK students towards the information usefulness of YouTube. The study has the following objectives:

i. To find out the extent of YouTube usage among UNIZIK students

ii. To examine the perception of the students towards the information usefulness of YouTube.

iii. To investigate the challenges in the use of YouTube as information source among the students.

\section{RESEARCH QUESTIONS}

The objectives gave rise to these research questions:

* To what extent do UNIZIK students use YouTube?

* What are the perceptions of the students towards information usefulness of YouTube?

* What challenges do the students encounter in using YouTube as an information source?

\section{LITERATURE REVIEW}

\section{Opposing view of YouTube}

Concerns over usefulness or credibility of YouTube have been raised by scholars and even by non scholars. Scholars like Ahlquist (2016) and Zhu (2017) uphold the usefulness of YouTube as information source especially in the education sector. Ahlquist (2016) writes: 'YouTube is changing the landscape of the world, including higher education'. YouTube's ability to change the landscape of the world and higher education implies that it is seen as useful source of information. Also Zhu (2017) has this to say: In the academic literature. 
DOI: doi.org/10.47851/naujocommed.v2i1.113

YouTube has been discussed in numerous ways: as a platform for higher education institutions to publish teaching materials, such as lectures and presentation videos, as a repository of video material for media collection of academic libraries and as a platform for alternative/citizen journalism.

Still on the acknowledgement of usefulness of YouTube as information source, Catapano (2009-2019) adds: 'YouTube has become a perfect place for entertainment and knowledge or both in the same video'. Other researchers perceive YouTube as an unreliable source based on the argument that anyone can create and upload information on the site as evidenced in this statement:

\begin{abstract}
YouTube lack of filter allows anyone (with the technology) to speak through it. This empowers people with unproven viewpoints and ideas that run counter to facts to gain an audience and can help them stay relevant. This right here is why YouTube isn't and will never be a scholarly or journalistic outlet (Gonzalez, 2016). Gonzalez goes on to say that YouTube itself is not a reliable source but that it does not mean that YouTube cannot be used to form arguments. He adds: 'Things on YouTube are absolutely not correct by virtue of being on YouTube'. On their part, Pant et al (2012) found out from a study on credibility of YouTube video information that information on YouTube is not regulated and can easily mislead those seeking it.
\end{abstract}

\title{
INFORMATION USEFULNESS OF YOUTUBE
}

YouTube is a great and amazing site where conversations take place between and among people. YouTube is one of the social sharing sites. It is an amazing site for creative of every faith and perspectives, and a place people from all over the world call their digital home (Gonzalez, 2016). YouTube educates and entertains its audience just like the mass media but has the advantage of user-generated content over the mass media. It is a free site where people can upload information at will with or without the technical know-how as long as one has the device. Soffar (2015) shares this view thus: 'YouTube is easy to use even for those students who have no computer skills at all. All you need do is to click on the play button and the video tutorial starts playing'. The simplicity of YouTube is one of the many reasons why it has exploded in popularity over the years (Mohsin, 2019).

Academics and students can exploit the site very well because it enhances classroom interaction. YouTube has the attribute of showcasing any topic that students find difficult to understand during normal physical class teaching to be learnt better with the use of video clips. Students search for many difficult or rather practical courses via YouTube as it gives them opportunities to have access to different uploads from different contributors on a particular subject matter. Pappas (2015) maintains that YouTube encourages students to develop their note-taking skills by viewing, rewinding and replaying the YouTube video materials until they have fully grasped its essence and key points. In addition, Hua (2015) is of the view that the very element of entertainment which students may not receive in class is what makes YouTube educational channels successful. Hua extols the great role entertainment plays in enhancing learning which is not common in physical classroom teaching and learning. Learning through entertainment can be likened to learning through role play which sustains attention and improves retention of what is taught.

Still on usefulness of YouTube, money can be earned on YouTube through Memberships. Stephenson (2019) states 'YouTube channel memberships are a way for fans to support their favourite YouTube channels by committing automated monthly donations'. Channel membership implies that a viewer having been impressed by the quality of content gotter 
DOI: doi.org/10.47851/naujocommed.v2i1.113

from a YouTube channel decides to commit financially to support the work of the content creator. This is different from subscriptions which is also a way YouTubers earn money. YouTubers are people who create contents on YouTube. Hubpages Inc. (2017) states: 'People can even earn from YouTube as people view the videos and advertisements'.

The monetization of YouTube works through advertising - just the same way as Television (Snickars \& Vonderau et al, 2009). Advert placement on YouTube can come in the form of sponsorship where a YouTuber personally endorses a product, service or brand in their video. YouTube offers students a window to the world where people are ready to pay and listen to something new and worth spending their time. Maximizing the great potentials of YouTube will help our economy to grow as YouTube is a lucrative source of income for YouTubers.

Sequel to this is that YouTube has been a valuable tool for marketing. Mohsin (2019) says: 'In recent years, more businesses have started to use YouTube as a channel to communicate with their existing customers and expose themselves to potential customers. As with the massive reach it has, it's no shocker that businesses are turning to YouTube to expand their marketing efforts'. In fact, there is no limit to potentials of YouTube as a credible social media and a video sharing site as long as one has the capabilities. Ahlquist (2016), citing Cayari (2011) captures it clearly:

\footnotetext{
YouTube is an art medium; a technology which allows listeners to become singers, watchers to become actors and customers to become producers creating new original works and supplementing existing ones. It allows everyone to have a voice that can be heard and a face that can be seen.
}

\section{EMPIRICAL STUDY ON YOUTUBE USE IN EDUCATION}

Many studies abound from literature search on educational use of YouTube. Such studies include studies conducted by Chtouki et al. (2012) and Orus et al (2016). Chtouki et al. (2012) studied the impact of YouTube on students' learning. The authors evaluated students' performance in an introduction to computers course for non-computer science students by comparing two groups of students. The first one was a test group in which students were supplied with a set of videos from YouTube to illustrate different concepts such as multiple core versus single core processes, hard disk internal components using fibre optic cables to connect under water.

The second was a control group in which traditional resources such as textbooks, in class lectures and handouts were used. The results of the study showed that students understood and could remember complex concepts much better when exposed to a visual explanation video. The study found out that most students if not all watched the short videos which was not the case with textual content. The result showed that YouTube videos actually enhance students' learning.

On their part, Orus et al (2016) conducted a study on the use of YouTube as a tool for learner-generated content and its effects on students' learning outcomes and satisfaction. The result of the study showed that despite the potentials of YouTube as a learning tool in education, its use as a learner-generated content is scarce. The findings showed that active participation of students in the creation of videos had a direct influence on the perceived acquisition of cross-curricular competencies and on academic performance even though the participation did not directly increase subjective learning or satisfaction with the course. It 
DOI: doi.org/10.47851/naujocommed.v2i1.113

showed that learner-generated content and use of YouTube as a teaching vehicle has a positive impact on students' learning outcomes and satisfaction.

\title{
THEORETICAL FRAMEWORK
}

Given that the study focused on investigating information usefulness of YouTube among Unizik students, perspectives from Technology Acceptance Model (TAM) presented the most productive explanatory framework for the study. TAM according to Davis (1989) cited in Charness \& Boot (2016 p.394) has been one of the most influential models of technology acceptance with two primary factors influencing an individual's intention to use new technology: perceived ease of use and perceived usefulness. YouTube is a relatively new technology and TAM proposes that perceived ease of use and usefulness of a technological tool and in this case, YouTube, determines the extent of consumer (university students) acceptance. Technology Acceptance Model assumes that:

\begin{abstract}
when users perceive that a type of technology is useful and easy to use, they will be willing to use it. Consequently, the more employees recognize that the system will make their tasks easier to perform; the higher is the probability that they will use it and accept the new technology as being useful (Dillon \& Morris, 1996) in (Ajibade, 2018 p. 3).
\end{abstract}

TAM, as applied to this study, is strictly for prediction of the outcome of the study. The expected outcome is either that university students have positive perception towards YouTube as a useful information source or that they have negative perception towards YouTube's usefulness. If the result of the study shows that the students have positive perception of YouTube and use it well, it agrees with the tenets of TAM

On the other hand, the students will not make good use of YouTube if they have negative perception towards its usefulness and if they find it difficult to use. TAM also justifies their action. Students are more likely to use YouTube to its fullest if they have positive perception towards it as a useful source of information and if they find it easy to use.

\section{METHODOLOGY}

This work employed the survey research design. The population of the study was every university regular student in Unizik. The study is purposively limited to students of Unizik (Nnamdi Azikiwe University, Awka), a Federal university in South-East Nigeria, Anambra State, with a population of 31,450 according to the Academic Planning Unit of the University. The choice of Unizik over other universities in the State was because it is a Federal and the biggest university in the State and therefore most likely to have more presence of students from the 3 major tribes (Igbo, Hausa and Yoruba) of Nigeria.

Multi stage sampling technique was used to select the required sample size. Unizik has 14 faculties and 4 were purposively selected because it is where the researchers have interest. The other ones can be taken up later. The 4 selected faculties were Education, Environmental Sciences, Social Sciences, and Pharmaceutical Sciences. From the faculties, 4 departments were selected using simple random sampling where names of all the departments in the 4 faculties were written on pieces of paper and folded. They were later put in a can and shuffled severally giving every department an equal chance of being picked and through a "lucky dip process', the 4 study departments were randomly picked. The departments were: Early Childhood \& Primary Education, Surveying and Geoinformatics, Mass Communication and Pharmaceutical Chemistry. 
A sample size of 400 implying 100 students per department was purposively decided upon as the most conservative for a 5 percent error tolerance. This purposive decision was based on the ranking of sample sizes by Comrey and Lee (1992) cited in Ono (2015) as: $100=$ poor, $200=$ fair, $300=$ good, $400=$ very good, 500 and above $=$ excellent. Table 1 shows the faculties and departments selected.

Table 1: Selection of Faculties and Departments

\begin{tabular}{lll}
\hline FACULTY & DEPARTMENT & DEPARTMENT \\
\hline Education & $\begin{array}{l}\text { Early Childhood \& Primary } \\
\text { Education }\end{array}$ & 100 \\
$\begin{array}{l}\text { Environmental } \\
\text { Sciences }\end{array}$ & $\begin{array}{l}\text { Surveying and Geoinformatics } \\
\text { Social Sciences }\end{array}$ & 100 \\
Pharmaceutical & Mass Communication & 100 \\
Sciences & Pharmaceutical Chemistry & 100 \\
Total & & 400 \\
\hline
\end{tabular}

Data collection instrument used for the study was questionnaire and the 400 students were administered copies of the questionnaire. Each copy of the questionnaire was taken back immediately it was completed, except a handful that were returned after a few days. Data were collected and analysed using frequency tables and pie-chats.

Analysis: Demographic Data of Respondents

Table 2: Age

\begin{tabular}{lll}
\hline Variables & No. of Respondents & Percentage Response \\
\hline $16-20$ & 139 & $34 \%$ \\
$21-25$ & 174 & $44 \%$ \\
$26-30$ & 54 & $14 \%$ \\
$31-35$ & 21 & $5 \%$ \\
36 and above & 12 & $3 \%$ \\
Total & 400 & $100 \%$ \\
\hline
\end{tabular}

Data in Table 2 show that respondents within 21-25 and 16-20 were predominant at 44 and 34 percent respectively. Less than one-fifth were within the other age brackets: 26-30 (14 percent), 31-35 (5 percent) and 36 and above ( 3 percent). This implies that majority of the respondents were within 21-25 age bracket.

Table 3: Respondents' Gender

\begin{tabular}{lll}
\hline Variables & No. of Respondents & Percentage Response \\
\hline Male & 179 & $45 \%$ \\
Female & 221 & $55 \%$ \\
Total & 400 & $100 \%$ \\
\hline
\end{tabular}

Table 3 shows that there were more female respondents than males. While 221 out of 400 (55 percent) were females, 179 out of 400 (45 percent) were males.

Table 4: Current Year of Study

Variables No. of Respondents Percentage Response 
NNAMDI AZIKIWE UNIVERSITY

Volume 2 Number 1 Jan-Mar Issue

DOI: doi.org/10.47851/naujocommed.v2i1.113

\begin{tabular}{lll}
\hline 100 level & 29 & $7 \%$ \\
200 level & 76 & $19 \%$ \\
300 level & 140 & $35 \%$ \\
400 level & 155 & $39 \%$ \\
Total & 400 & $100 \%$ \\
\hline
\end{tabular}

Table 4 shows a high of 39 percent (155 out of 400) for 400 level students and a low of 7 percent (29 out of 400) for 100 level students. Respondents in 200 and 300 levels were 19 percent and 35 percent respectively. The data imply that there were more 400 level students as respondents.

Table 5: Questionnaire Return Rate

\begin{tabular}{llll}
\hline Respondents & $\begin{array}{l}\text { Copies } \\
\text { distributed }\end{array}$ & $\begin{array}{l}\text { Copies } \\
\text { returned }\end{array}$ & $\begin{array}{l}\text { Percentage } \\
\text { returned }\end{array}$ \\
\hline Students & 400 & 400 & 100 \\
Total & 400 & 400 & 100 \\
\hline
\end{tabular}

Table 5 shows that the entire 400 copies of questionnaire were filled and returned, making it a $100 \%$ return rate. No copy was lost. This is good and shows the commitment of the researchers to the study.

\section{ANALYSIS OF RESEARCH QUESTIONS}

\section{1: Research Question 1: To what extent do Unizik students use YouTube?}

Here, the respondents were asked their extent of YouTube use and their responses were as recorded in Figure 1.

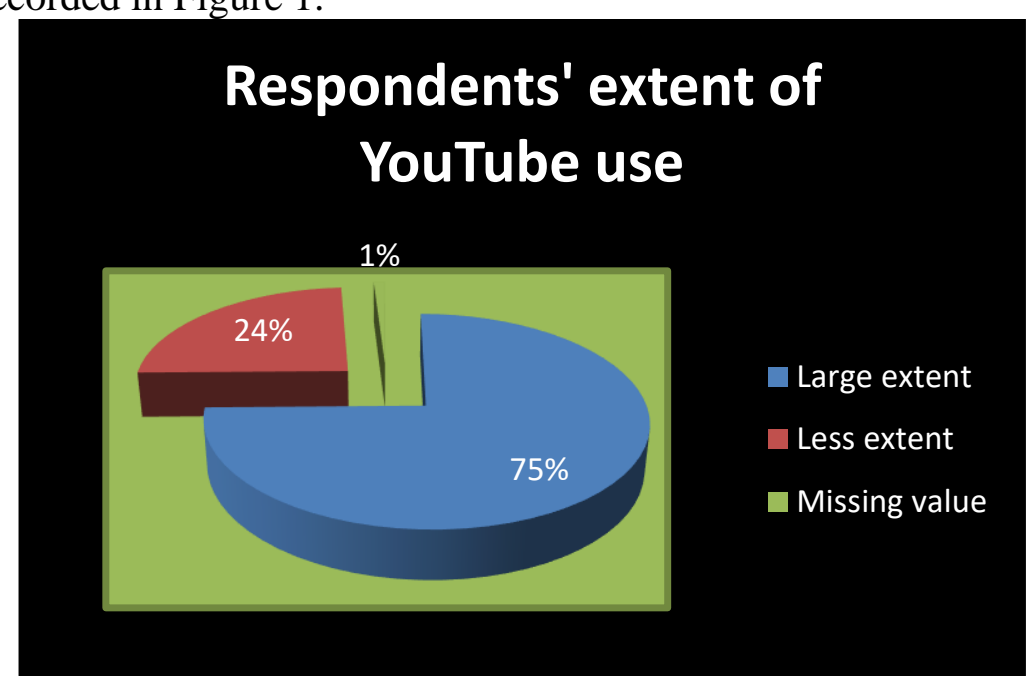

Figure 1: Extent of YouTube use

Figure 1 shows a high of 75 percent (299 out of 400) of respondents who used YouTube to a large extent and a low of 24 percent (97 out of 400) of respondents who used it to a less extent. The data also show that 1 percent (4 out 400) of the respondents did not answer the question probably out of oversight. The implication is that majority of the respondents use YouTube to a large extent possibly because they perceive it as very useful and easy to use.

A follow up question was asked to ascertain the type of information the students accessed from YouTube since majority of them claimed to use the technology to a large extent: 'What 
Volume 2 Number 1 Jan-Mar Issue

DOI: $\underline{\text { doi.org/10.47851/naujocommed.v2i1.113 }}$

type of information do you access from YouTube most of the time?' Their responses were recorded in Table 6.

Table 6: Type of information accessed from YouTube most of the time

\begin{tabular}{lll}
\hline Variables & No. of Respondents & $\%$ Response \\
\hline Entertainment & 156 & $39 \%$ \\
Education & 16 & $4 \%$ \\
Politics & 36 & $9 \%$ \\
Business/entrepreneurship & 137 & $34 \%$ \\
All & 55 & $14 \%$ \\
Missing value & Nil & - \\
Total & 400 & $100 \%$ \\
\hline
\end{tabular}

Table 6 shows that information on entertainment was accessed more than every other information that YouTube offers while education was the least accessed even when the respondents were students. As students, it was expected that they would access information on education more than every other information but the reverse was the case. This might be because they have other apps for educational information. While 156 out of $400(39 \%)$ respondents accessed information on entertainment, only 16 out of 400 (4\%) respondents accessed academics or educational information. Next to entertainment is business/entrepreneurship which had 137 out of 400 (34\%) respondents. Politics has 36 out of $400(9 \%)$ and "All' 55 out of $400(14 \%)$ respondents. It can be observed from the data that all the respondents (400 of them) answered the question including the 4 respondents who did not answer the previous linking question as shown in Table 3. The data imply that the respondents actually use the technology since they accessed the types of information that are available on YouTube.

\section{2: Research Question 2: 'What are your perceptions towards information usefulness of YouTube?'}

Here, the researchers wanted to find out the respondents' perceptions towards information usefulness of YouTube having shown that they used it to a large extent and accessed the types of information therein. Their responses were as recorded in Figure 2. 


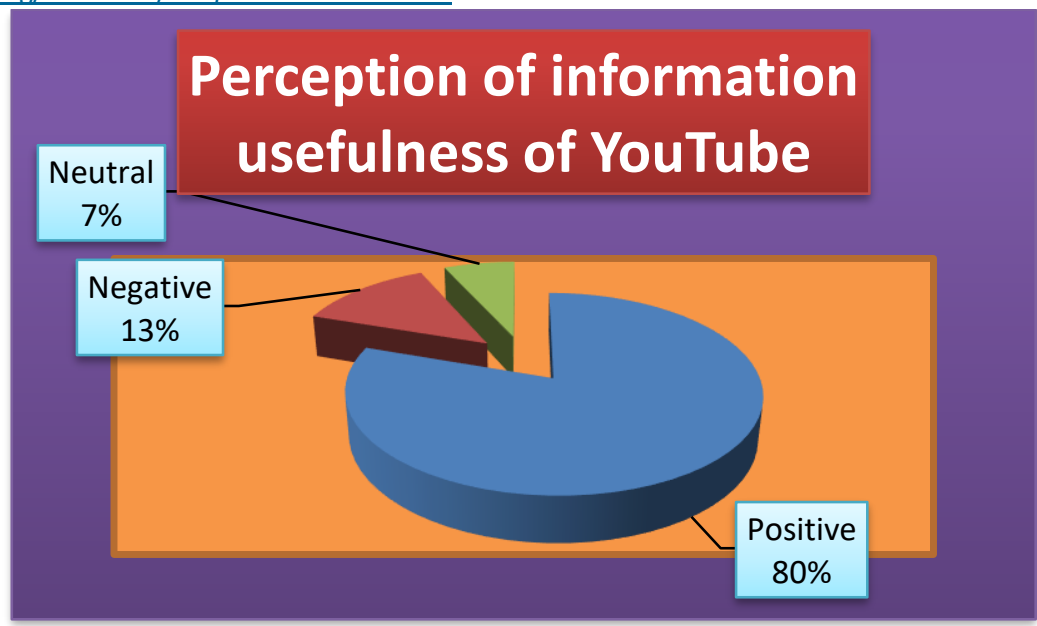

Figure 2: Perception of information usefulness of YouTube

Figure 2 shows that four-fifth $(80 \%)$ of the respondents had positive perception towards information usefulness of YouTube while about one-tenth (13\%) had negative perception. Also, less than one-tenth (7\%) of the respondents was neutral about YouTube's usefulness as information source. They neither perceived YouTube positively nor negatively as useful information source implying that they probably doubted the credibility of YouTube's information. That majority of the respondents had positive perception towards information usefulness of YouTube implies that they believed YouTube information as credible.

Next, a question was asked to ascertain why YouTube was positively perceived as useful information source: 'If positive, why do you perceive YouTube as useful source of information?' Figure 3 shows their responses to the question:

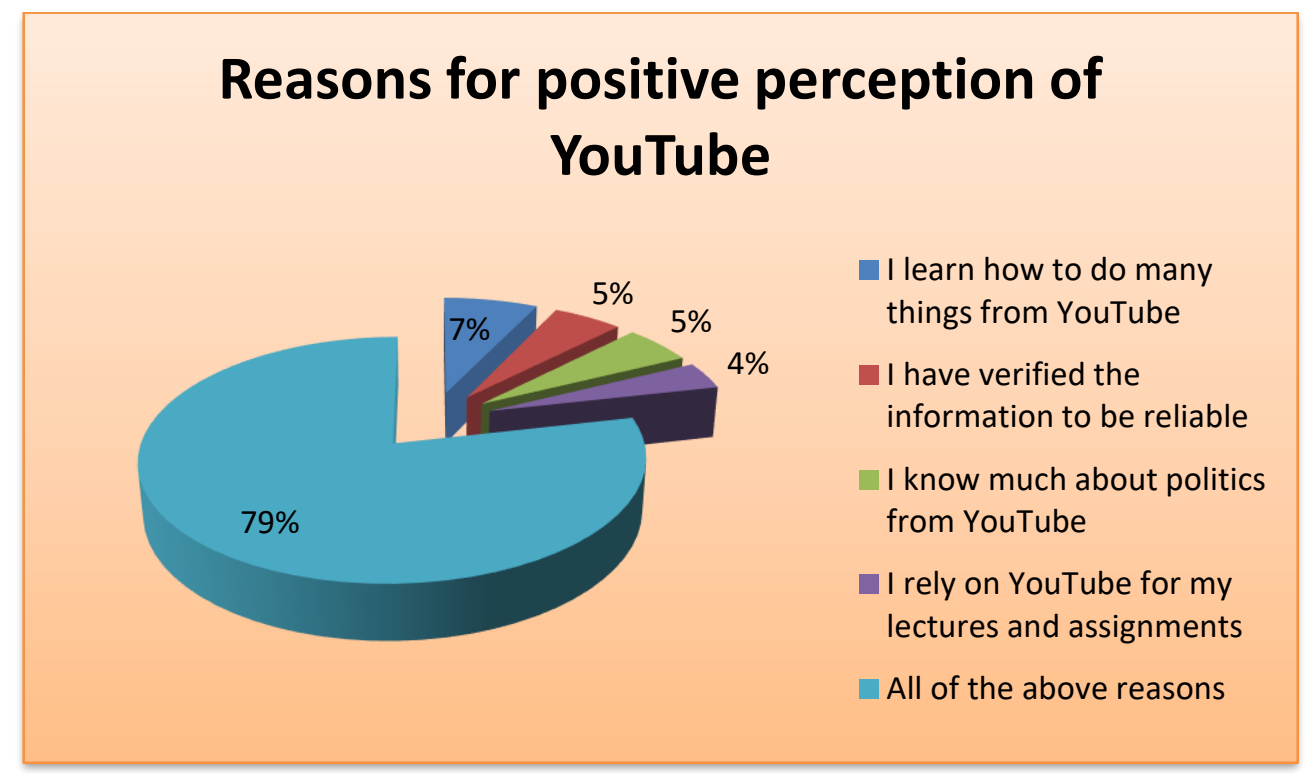

Figure 3: Reasons for positive perception towards information usefulness of YouTube

Data in Figure 3 show that the respondents actually had positive perception towards information usefulness of YouTube. As much as 252 out of 321 (79\%) respondents had positive perceptions and they gave all the listed reasons for this perception. Less than one- 
DOI: doi.org/10.47851/naujocommed.v2i1.113

tenth picked the other options respectively. The result implies that the students had good reasons for their positive perception towards information usefulness of YouTube.

Next, those who had negative perception towards information usefulness of YouTube were also asked their reasons: 'If negative, why do you perceive it so?' Their responses were as recorded in Table 7:

Table 7: Reasons for negative perception of information usefulness of YouTube

\begin{tabular}{|c|c|c|}
\hline Variables & $\begin{array}{l}\text { No. of } \\
\text { Respondents }\end{array}$ & $\%$ Response \\
\hline $\begin{array}{l}\text { Anybody can send anything } \\
\text { on the site }\end{array}$ & Nil & - \\
\hline $\begin{array}{l}\text { The authors do not have their } \\
\text { details attached to their videos }\end{array}$ & Nil & - \\
\hline It is full of lies & Nil & - \\
\hline $\begin{array}{l}\text { YouTube is meant for just } \\
\text { entertainment and nothing } \\
\text { more }\end{array}$ & Nil & - \\
\hline All of the above & 52 & $100 \%$ \\
\hline Total & 52 & $100 \%$ \\
\hline
\end{tabular}

Data in Table 7 show an interesting result. All of the respondents 52 out of $52(100 \%)$ who had negative perceptions towards information usefulness of YouTube had the same reasons for their perception. They all completed the 'All of the above' option. This implies that they had strong negative perception towards information usefulness of YouTube.

\section{3: Research Question 3: 'What challenges do you encounter in using YouTube as information source?}

Here, the researchers wanted to ascertain the challenges the respondents encountered in using YouTube since majority of them used the technology to a large extent and had positive perception towards its information usefulness. This question became necessary as it helped in finding out some reasons for poor usage of YouTube in Nigeria.

Table 8: Challenges of using YouTube

\begin{tabular}{llll}
\hline Variables & No. of Respondents & $\%$ Response \\
\hline $\begin{array}{l}\text { Unavailability } \\
\text { connectivity }\end{array}$ & of & internet & 99 \\
High cost of data & & 210 & \\
Poor patronage as content creators & 35 & $52 \%$ \\
All of the above & 56 & $9 \%$ \\
Total & 400 & $14 \%$ \\
\hline
\end{tabular}

Data in Table 8 show the various challenges the respondents had in using YouTube. Over half of them (52\%) had 'High cost of data' challenge; one-fourth $(25 \%)$ said 'Unavailability of internet connectivity'; less than twenty percent (14\%) said 'All of the above' while less than ten percent $(9 \%)$ had 'Poor patronage as content creators' challenge. It can be observed from the data that many respondents were not content creators because of low patronage from people. This poses a major challenge even when YouTube has been acclaimed to be a 
DOI: doi.org/10.47851/naujocommed.v2i1.113

lucrative tool. High cost of buying data challenge will remain unless the government subsidises the cost of data. These challenges are part of the reasons why there is low viewership of YouTube in Nigeria even among older persons.

\section{DISCUSSION OF FINDINGS}

The main purpose of the study was to find out the perception of Unizik students towards the information usefulness of YouTube. The objectives included to find out the extent of YouTube use among the students and the challenges they had in using YouTube following the reported underutilization of YouTube in Nigeria. Select Unizik students were understudied to represent the entire students studying in the university. The study design was survey and questionnaire served as the instrument of data collection. Data were analysed using frequency tables and pie charts. Copies of the questionnaire were distributed to the students and all the copies were returned given a $100 \%$ return rate.

The study found out that majority (75 percent) of the students used YouTube to a very large extent and they accessed information on entertainment and business/entrepreneurship most of the time in spite of the challenges they encountered with its use. Education was the least accessed information even as students. Apart from watching the videos for entertainment, the students learn skills possibly to make a living out of YouTube which is encouraging. The challenges included among others the high cost of buying data because they are not a working class group and unavailability of internet connectivity which seems to be a general challenge in developing nations. The study also found out that the students had positive or good perceptions towards the information usefulness of YouTube and they had justifiable reasons for their perceptions.

\section{CONCLUSION AND RECOMMENDATIONS}

From the results and discussion of findings above, it can be concluded that low viewership of YouTube in Nigeria is not because students do not make use of the site. The study showed that majority of the students ( 80 percent) had positive perception towards the information usefulness of YouTube and therefore make good use of the site in spite of its significant challenges especially high cost of data and poor network connectivity. Their perception has nothing to do with low viewership of the site too. The students were aware that money could be made from YouTube but majority of them were not content producers because of poor patronage challenge.

The researchers therefore recommend that government should subsidize the cost of data for accessing YouTube and improve on the poor network connectivity so as to avail students the opportunities of making maximum use of YouTube as a significant source of information, knowledge and employment. This would help to contain the unemployment menace in Nigeria. More research is recommended to find out reasons for poor usage of YouTube in Nigeria. Free educational YouTube site should be made available for countries with low viewership to aid students and staff access educational videos for academic purposes.

\section{REFERENCES}

Ahlquist, J. (2016). How YouTube is impacting current and future college students. Retrieved from https://linkedin.com 30-10-2019

Ajibade, P. (2018). Technology acceptance model limitations and criticisms: Exploring the practical applications and use in technology-related studies, mixed-method, and qualitative researches. Retrieved from https://digitalcommon.unl.edu 07- 10- 2019 
Busari, S. \& Osman, O. M. (2017). Nigerians can now view YouYube offline. Retrieved from https://www.google,com 11-10-2019.

Catapano, J. (2009-2019). Technology in the classroom: Using YouTube. Retrieved from https://teachhub.com 29-10-2019

Charness, N. \& Boot, W. R. (2016). Technology, gaming, and social networking. Retrieved from http://dx.doi.org 07-10-2019

Chtouki, Y. et al (2012). The impact of YouTube on the students' learning. Retrieved from https://www.semantics.org 23-04-2021

Clement, J. (2019). Nigeria: number of internet users 2017-2023. Retrieved from http://www.statista.com 29-11-2019

Daniel, V. (2021). 25 YouTube statistics that everyone should know in 2021 (For improved marketing). Retrieved from https://www.otterpr.com 25-04-2021

Gonzalez, L. (2016). Is YouTube a reliable source? Retrieved from https://patheos.com 3009-2019

Ho, V. (2017). Data friendly YouTube Go comes out in beta in Southeast Asia. Retrieved from http://www.mashable.com 20-09-2019

Hua, K. (2015). Education as Entertainment: YouTube Sensations Teaching the Future. Retrieved from http://www.forbes.com 12-12-2019

Hubpages Inc. (2017). The advantages and disadvantages of YouTube. Retrieved from https://hubpages.com 28-12-2019

Iqbal, M. (2020). YouTube revenue and usage statistics. Retrieved from https://www.businessofapps.com 20-04-2021

John, J. (2021). Only $15.8 \%$ of Nigeria's population is active on social media-Digital report 2021. Retrieved from https://www.nairametrics.com 26-04-2021

Kazeem, Y. (2017). Google wants to bypass Nigeria's slow internet with its "offline first" YouTube. Retrieved from https://qz.com 12-11-2019

Lee, K., Son, G. (...), \& Park, S. T. (2020). YouTube as a source of information and education on hysterectomy. JKMS Journal of Korean medical science. 35(25): e196. Retrieved from https://www.ncbi,nlm.nih.gov

Mohsin, M. (2019). 10 YouTube stats every marketer should know in 2020. Retrieved from https://oberlo.com 28-12-2019

Mohsin, M. (2021). 10 YouTube stats every marketer should know in2021 (Infographic). https://www.ng.oberlo.com 24-04-2021 
Online Media News Nigeria (2011). YouTube launches in Nigeria. Retrieved from https://www.bizcommunity.com.ng 12-11-2019

Ono, G. N. (2015). Assessment of NAFDAC media campaign to change consumers 'attitudes and behaviours towards food and medication drugs in South East Nigeria. An unpublished Ph.D dissertation, department of Mass Communication, Nnamdi Azikiwe University, Awka, Anambra State, Nigeria.

Orus, C. et al (2016). The use of YouTube as a tool for learner-generated content: Effects on students' learning outcomes and satisfaction. Retrieved from https://researchgate.net $18-12-2019$

Pant, S. et al. (2012). Assessing the credibility of the 'YouTube Approach to health information on acute myocardial infarction. Retrieved from https://reserachgate.net 29-12-2019

Pappas, C. (2015). 8 important reasons why YouTube should be part of your elearning course. Retrieved from https://freedutech.com 17-12-2019

Snickars, P. \& Vonderau, P. (2009). The YouTube Reader. Logotipas, Lithuania. ISSN: 1654-6601.

Soffar, H. (2015). What are the advantages and disadvantages of using YouTube? Retrieved from https://onlinesciences.com 02-10-2019

StatCounter (1999-2021). Social media stats in Nigeria. Retrieved from https://gs.statcounter.com/social-media-stats/all/nigeria

Stephenson, B. (2019). How do YouTube channel memberships work? Retrieved from https://lifewire.com 07-09-2019

Varrella, S. (2021). Leading social media platforms in Nigeria 2020. Retrieved from https://www.statista.com 23-04-2020

Wesch, M. (2008). An Anthropological Introduction to YouTube. Retrieved from http://m.YouTube.com

Zhu, Y. (2017). Academics' active and passive use of YouTube for research and leisure. Retrieved from https://igi-global.com 29-08-2019 